\title{
Investigation of Pediatric Poisoning in Aksaray
}

\section{Aksaray'da Çocuk Zehirlenmesinin Araştırılması}

\author{
@Emine Özdemir Kaçer, @ilker Kaçer², @Hanife Tuğçe Çağlar ${ }^{3}$ \\ 'Aksaray University School of Medicine Department of Pediatrics, Aksaray, Turkey \\ ${ }^{2}$ Aksaray University Aksaray Education and Research Hospital, Department of Emergency Medicine, Aksaray, Turkey \\ ${ }^{3}$ Republic of Turkey Ministry of Health Aksaray Ortaköy State Hospital, Aksaray, Turkey
}

\begin{abstract}
Introduction: Pediatric poisoning is a common cause of emergency department admissions. The epidemiology of pediatric poisonings can vary in different countries, even different regions of the same country. It is important to determine the regional factors to decrease morbidity and mortality. This study was aimed to evaluate the epidemiological features, clinical signs, and risk factors of pediatric poisonings.

Material and Method: This retrospective descriptive study was carried out in the pediatric emergency department of a tertiary hospital and medical records between January 2016 and December 2020 were retrospectively reviewed. Demographic characteristics, laboratory results, and treatments were recorded.

Results: 835 patients aged 4 months- 18 years including 450 females (53.9\%) were included in the study. Poisonings were most common in summer $(n=280,33.5 \%)$ and in the daytime $(n=490$, $58.7 \%$ ). The mean age of suicidal poisoning was significantly higher then accidental poisonings $(p<0.001)$. Pharmaceutical agents were statistically significantly higher in patients poisoned due to suicidal attempts $(p<0.001)$. On the other hand, there was not a statistically significant difference between accidental and suicidal poisoning in terms of clinical presentation, length of stay in the hospital, and, intensive care unit requirement ( $p>0.05)$.

Conclusions: Childhood poisoning is one of the important emergencies that need attention. Pediatric emergency physicians should always keep in mind the possibility of poisoning, even with the lack of medical history. It could be estimated the possible ingested agents according to the age group, and this allows physicians to avoid delay in treatment of these patients.
\end{abstract}

Keywords: Pediatric poisoning, pediatric emergency medicine, suicide, accident

\section{Öz}

Giriş: Pediatrik zehirlenme, acil servise başvuruların yaygın bir nedenidir. Pediatrik zehirlenmelerin epidemiyolojisi farklı ülkelerde, hatta aynı ülkenin farklı bölgelerinde bile değişebilir. Morbidite ve mortaliteyi azaltmak için bölgesel faktörlerin belirlenmesi önemlidir. Bu çalışmada çocukluk çağı zehirlenmelerinin epidemiyolojik özellikleri, klinik bulguları ve risk faktörlerinin değerlendirilmesi amaçlanmıştır.

Gereç ve Yöntem: Bu retrospektif tanımlayıcı çalışma, üçüncü basamak bir hastanenin pediatrik acil servisinde gerçekleştirildi ve Ocak 2016 ile Aralık 2020 arasındaki tıbbi kayıtlar geriye dönük olarak incelendi. Demografik özellikler, laboratuvar sonuçları ve tedaviler kaydedildi.

Bulgular: Çalışmaya 450 kadın (\%53.9) olmak üzere 4 ay-18 yaş arası 835 hasta dahil edildi. Zehirlenmeler en sık yazın $(n=280, \% 33,5)$ ve gündüz ( $n=490, \% 58,7)$ mevsiminde görüldü. Ortalama intihar zehirlenmesi yaşı, kaza sonucu zehirlenmelere göre anlamlı derecede yüksekti ( $p<0.001)$. İntihar girişimi nedeniyle zehirlenen hastalarda ilaç ajanları istatistiksel olarak anlamlı derecede yüksekti $(p<0,001)$. Öte yandan kaza ve intihar zehirlenmeleri arasında klinik prezentasyon, hastanede kalış süresi ve yoğun bakım ünitesi gereksinimi açısından istatistiksel olarak anlamlı fark yoktu $(p>0,05)$.

Sonuçlar: Çocukluk çağı zehirlenmesi, dikkat edilmesi gereken önemli acil durumlardan biridir. Pediatrik acil hekimleri, tıbbi öykü olmasa bile zehirlenme olasılığını her zaman akılda tutmalıdır. Yaş grubuna göre alınabilecek olası etkenler tahmin edilebilir ve bu, hekimlerin bu hastaların tedavisinde gecikmelerden kaçınmasını sağlar.

Anahtar kelimeler: Pediatrik zehirlenme, pediatrik acil tıp, intihar, kaza

Corresponding (iletişim): Illker Kaçer, Aksaray University Aksaray Education and Research Hospital, Department of Emergency Medicine, Aksaray, Turkey

E-mail (E-posta): ik0626@hotmail.com

Received (Geliş Tarihi): 28.03.2021 Accepted (Kabul Tarihi): 26.07.2021 


\section{INTRODUCTION}

Pediatric poisoning is a common cause of emergency department admissions. ${ }^{[1]}$ In 2019, 1,236,227 (57.5\% of all ages) individuals under the age of 20 were admitted to the pediatric emergency department (ED) due to poisoning in the United States. ${ }^{[2]}$ While the rate of poisoning was 0.5 per 100,000 population in developed countries, it was 2 per 100,000 population in developing countries. ${ }^{[3]}$

Pediatric poisonings can occur accidentally or intentionally. While accidental poisoning is more common in children under 5 years and boys, intentional poisoning is more common in adolescents and girls. ${ }^{[4,5]}$ Household cleaning products, gas oil, thinner, toxic gases, prescribed/nonprescribed drugs, insecticides, and pesticides are the most common causes of poisoning in childhood. ${ }^{[6,7]}$

The epidemiology of pediatric poisonings can vary in different countries, even different regions of the same country. It is important to determine the regional factors to decrease morbidity and mortality. Therefore, the present study was aimed to evaluate the epidemiological features, clinical signs, and risk factors of pediatric poisonings.

\section{MATERIAL AND METHOD}

This retrospective descriptive study was carried out in the pediatric emergency department of a tertiary hospital in the Aksaray, Central Anatolian region of Turkey, and approved by the local ethical committee (2021/01-54).

\section{Study population and setting}

The medical records of all poisoning-related admissions to the pediatric emergency department between January 2016 and December 2020 were retrospectively reviewed. The study was included the following patients: 1 ) those aged $<18$ years; and 2) those diagnosed with acute poisoning at the pediatric emergency department. The following patients were excluded:1) those aged $>18$ years; 2 ) those poisoned due to food over-ingestion except for the mushroom and plant poisonings; 3 ) those poisoned due to foreign body ingestion (coins, plastics, or toys); 4) those poisoned due to vaccination; and 5) those with missing data.

Age (0-5, 6-12, and 13-18 years), gender, admission time (night, 00:00-08:00; daytime, 08:00-16:00; and evening, 16:00-00:00), admission season (winter, spring, summer, and autumn), poisoning agent (pharmaceutical and non-pharmaceutical), cause of poisoning (accidental and suicidal), location of the poison exposure (home and outside home), medical history of the previous poisoning, symptoms at the admission (nauseavomiting, dizziness, mucosal erythema-edema, abdominal pain, confusion, shortness of breath and cough, tachycardia, mydriasismiosis, and hypotension-shock), the length of stay in the hospital (hours), the requirement of intensive care unit and mortality were recorded. Patients poisoned with a pharmaceutical agent were divided into six major groups based on the categories of pharmaceutical: (1) neurologic system agents (anxiolytic/ hypnotic agents, antidepressant agents, antiepileptic drugs, and narcotics); (2) analgesics (acetaminophen and nonsteroid anti-inflammatory drugs); (3) respiratory system agents (bronchodilators and dextromethorphan); (4) cardiovascular system agents (antihypertensive drugs and anticoagulants); (5) metabolic and nutrient agents (vitamins and iron); and (6) others (7). Non-pharmaceutical agents were categorized as (1) alcohol, drug; (2) carbon monoxide; (3) corrosive substances (cleaning substances, deodorizers, desiccants, personal care products); (4) mushrooms, plants; (5) venoms (bite or sting); and (6) insecticides, herbicides, rodenticides.

\section{Data Analysis}

Data were analyzed using Statistical package social sciences (SPSS, version 22.0 Inc., Chicago IL, USA). Descriptive analyzes were expressed as number (\%) for categorical variables, and mean \pm standard deviation (SD) for normally distributed variables (age and length of stay in hospital). In the comparison of accidental and suicidal poisonings, chi-square and Fischer exact test was used for categorical variables, whereas Student's t-test was used for continuous variables. A p-value of $<0.05$ was considered statistically significant.

\section{RESULTS}

In the pediatric emergency department, 1,164 children were diagnosed with poisoning during the study period. Seventy-two patients who had missing data, 210 patients who were poisoned due to food over-ingestion, 45 patients who were poisoned due to foreign body ingestions, and two patients who poisoned due to vaccination were excluded from the study. Finally, 835 patients aged 4 months-18 years (mean $77.67 \pm 59.21$ months) including 450 females (53.9\%) were included in the study.

Poisonings were most common in summer $(n=280,33.5 \%)$ and in the daytime $(n=490,58.7 \%)$. Three hundred and fiftynine $(43 \%)$ patients were poisoned due to pharmaceutical agents, whereas $476(57 \%)$ patients were poisoned due to non-pharmaceutical agents. The reason for poisoning was a suicide attempt in $138(16.5 \%)$ patients and $81(9.7 \%)$ patients had a history of the previous poisoning. Five hundred and thirty-three patients (63.8\%) were asymptomatic. Among symptomatic patients $(n=302,36.2 \%)$, the most common symptom was nausea-vomiting $(n=83,27.4 \%)$, followed by dizziness ( $n=46,15.2 \%)$, and multiple symptoms ( $n=40,13.2 \%)$. The mean length of stay in the hospital was $28.35 \pm 12.87$ (median=27, min-max=4-105) hours. Twenty-two (2.6\%) patients required intensive care unit (ICU) admission. The baseline characteristics of the study population according to the age groups were summarized in Table 1.

There was only one patient who died due to poisoning during the study period. She was 211 months old, had not a history of previous poisoning, or a psychiatric disorder. She took her grandmothers' verapamil tablets at 03:30 AM, at home. She was hemodynamically unstable at the admission to the pediatric emergency department. She was admitted to the ICU and died at the 4th hour of treatment. 


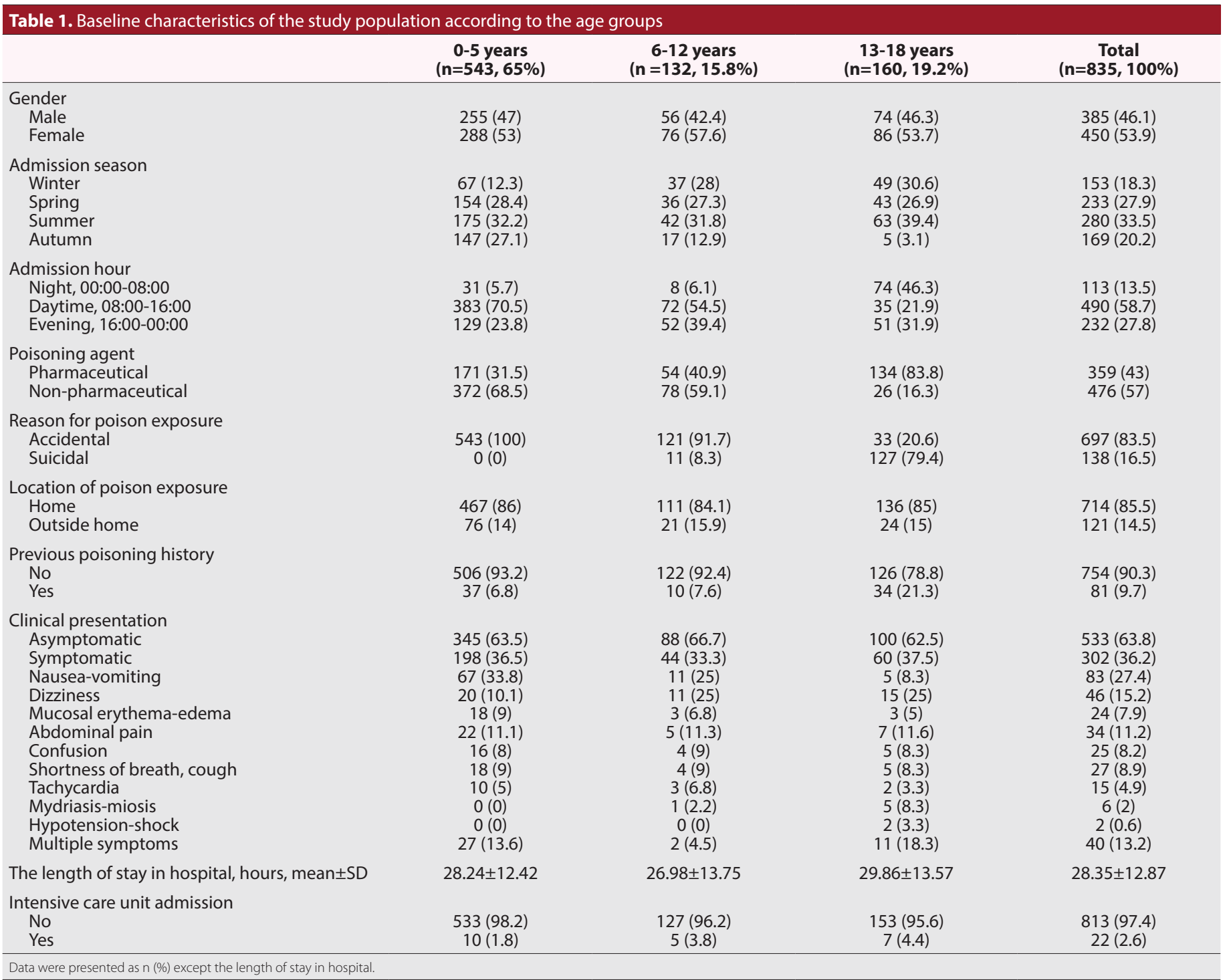

Analgesics were the most common ( $n=136,37.9 \%)$ pharmaceutical poisons, followed by neurologic system agents $(n=82,22.8 \%)$, and cardiovascular system agents $(n=43,12 \%)$. Corrosive substances were the most common ( $n=167,35.1 \%$ ) non-pharmaceutical poisons, followed by carbon monoxide $(n=153,32.1 \%)$, and mushrooms and plants $(n=52,10.9 \%)$. Detailed information on agents causing the studied poisonings is presented in Table 2.

The mean age of suicidal poisoning was significantly higher then accidental poisonings (179.28 \pm 31.65 months, $p<0.001)$. At night, between 00:00 and 08:00, the poisonings were more likely to be result of suicidal attempts $(p<0.001)$. Pharmaceutical agents were statistically significantly higher in patients poisoned due to suicidal attempts $(p<0.001)$. On the other hand, there was not a statistically significant difference between accidental and suicidal poisoning in terms of clinical presentation, length of stay in the hospital, and, ICU requirement ( $p>0.05)$. The comparison of accidental and suicidal poisonings is summarized in Table 3.

\section{Table 2. Detailed information on agents causing the studied poisonings}

Pharmaceutical poisons $359(43)$

Neurologic system agents

$82(22.8)$

Analgesics

$136(37.9)$

Respiratory system agents

$27(7.5)$

Cardiovascular system agents

$43(12)$

Metabolic and nutrient agents

$36(10)$

Others

$35(9.7)$

Non-pharmaceutical agents

$476(57)$

Alcohol, drug

$47(9.9)$

Carbon monoxide

$153(32.1)$

Corrosive substances

167 (35.1)

Mushrooms, plants

$52(10.9)$

Venoms (bite or sting)

$34(7.1)$

Insecticides, herbicides, rodenticides

$23(4.8)$

Data were presented as $n(\%)$ except age and the length of stay in hospital. 


\begin{tabular}{|c|c|c|c|}
\hline & $\begin{array}{c}\text { Accidental } \\
(n=697)\end{array}$ & $\begin{array}{l}\text { Suicidal } \\
(n=138)\end{array}$ & P value \\
\hline Age, months, mean $\pm S D$ & $57.55 \pm 39.39$ & $179.28 \pm 31.65$ & $<0.001$ \\
\hline $\begin{array}{l}\text { Gender, n (\%) } \\
\text { Male } \\
\text { Female }\end{array}$ & $\begin{array}{l}317(45.5) \\
380(54.5)\end{array}$ & $\begin{array}{l}68(49.3) \\
70(50.7)\end{array}$ & 0.414 \\
\hline $\begin{array}{l}\text { Admission season, } \mathrm{n}(\%) \\
\text { Winter } \\
\text { Spring } \\
\text { Summer } \\
\text { Autumn }\end{array}$ & $\begin{array}{c}114(16.4) \\
189(27.1) \\
230(33) \\
164(23.5)\end{array}$ & $\begin{array}{l}39(28.3) \\
44(31.9) \\
50(36.2) \\
5(3.6)\end{array}$ & $<0.001^{*}$ \\
\hline $\begin{array}{l}\text { Admission hour, } \mathrm{n}(\%) \\
\text { Night, 00:00-08:00 } \\
\text { Daytime, 08:00-16:00 } \\
\text { Evening, 16:00-00:00 }\end{array}$ & $\begin{array}{c}42(6) \\
451(64.7) \\
204(29.3)\end{array}$ & $\begin{array}{l}71(51.4) \\
39(28.3) \\
28(20.3)\end{array}$ & $<0.001^{*}$ \\
\hline $\begin{array}{l}\text { Poisoning agent, } \mathrm{n}(\%) \\
\text { Pharmaceutical } \\
\text { Non-pharmaceutical }\end{array}$ & $\begin{array}{l}241(34.6) \\
456(65.4)\end{array}$ & $\begin{array}{l}118(85.5) \\
20(14.5)\end{array}$ & $<0.001$ \\
\hline $\begin{array}{l}\text { Location of poison exposure, } \mathrm{n}(\%) \\
\text { Home } \\
\text { Outside home }\end{array}$ & $\begin{array}{l}598(85.8) \\
99(14.2)\end{array}$ & $\begin{array}{l}116(84.1) \\
22(15.9)\end{array}$ & 0.596 \\
\hline $\begin{array}{l}\text { Previous poisoning history, } \mathrm{n}(\%) \\
\text { Yes } \\
\text { No }\end{array}$ & $\begin{array}{c}643(92.3) \\
54(7.7)\end{array}$ & $\begin{array}{l}111(80.4) \\
27(19.6)\end{array}$ & $<0.001$ \\
\hline $\begin{array}{l}\text { Clinical presentation, } \mathrm{n}(\%) \\
\text { Asymptomatic } \\
\text { Symptomatic }\end{array}$ & $\begin{array}{l}443(63.6) \\
254(36.4)\end{array}$ & $\begin{array}{l}90(65.2) \\
48(34.8)\end{array}$ & 0.711 \\
\hline $\begin{array}{l}\text { The length of stay in hospital, } \\
\text { hours, mean } \pm S D\end{array}$ & $28.32 \pm 13.55$ & $28.47 \pm 8.71$ & 0.173 \\
\hline $\begin{array}{l}\text { Intensive care unit admission, n (\%) } \\
\text { Yes } \\
\text { No }\end{array}$ & $\begin{array}{c}680(97.6) \\
17(2.4)\end{array}$ & $\begin{array}{c}133(96.4) \\
5(3.6)\end{array}$ & 0.389 \\
\hline
\end{tabular}

\section{DISCUSSION}

Acute poisoning in children is a life-threatening emergency. Epidemiological evaluations and identification of predisposing risk factors in this field can be a research priority, especially in our city where the population triples in summer. In every summer, approximately 1 million expatriate visits our city, and they affect the active lifestyles of local people. In our study, suicidal poisonings were increased in summer, in contrast with the literature, ${ }^{[8,9]}$ and this may be related to the changes in population structure in the summer months.

Regarding age distribution, most of the poisoning patients were under 5 years old, and they were poisoned more commonly in the daytime and summer, as expected. ${ }^{[8]}$ Considering that younger children spend more time outside the home, especially in the summer months, poisonings in this age group are expected to occur more outside the home. However, poisonings at home were more common in this age group in our study. The most common agents of poisonings were corrosive substances and carbon monoxide. This may explain the dominancy of home poisonings. In addition, poisonings that occurred outside of the home may be related to venoms and plants.

In the adolescent group, poisonings were more common at night hours, with pharmaceutical agents, and as suicide attempts, similar to the literature. ${ }^{[9,10]}$ An adolescent who plans to attempt suicide can read the contents of the drugs, understand the effects, reach enough dose, and hide them from parents. Lin et al. ${ }^{[1]]}$ reported a high rate of previous suicide attempt history in these patients. Yang et al. ${ }^{[10]}$ reported a $1.4 \%$ rate of mortality and suggested that pediatric poisoning is a fairly serious problem. In this study, 34 (21.3\%) patients in this age group had a suicide attempt history. Only one patient died due to verapamil intoxication. It was a planned suicide. On the other hand, most of the poisonings in this age group occurred at home. These suicide attempts at home may be aimed at secondary gains from parents or lovers, especially among female patients. ${ }^{[1,10]}$

Etiological causes of poisonings may vary according to the geographical region, socio-cultural and economic conditions of the societies. Therefore, each country, even each region, should determine its own poisoning agent and take necessary precautions according to the risks and threats it faces. However, in developing countries, it is difficult to predict the severity of childhood poisonings due to the lack of reliable data. In our country, drugs usually were the most common agents in childhood poisonings with a range of $43.6 \%-60 \%$, followed by corrosive substances, insecticides, and mushrooms. ${ }^{[12-19]}$ In this study, which is conducted in the Central Anatolian region of Turkey, the most common agents for poisonings were drugs, followed by corrosive substances, and carbon monoxide. The fact that coal stoves are used instead of natural gas in some villages of our region may be the reason why carbon monoxide poisoning is in the third place, in contrast with other studies from Turkey. In addition, similar to the literature from Turkey, the most common agents for pharmaceutical poisonings were analgesics, followed by neurologic system agents, and cardiovascular system agents. $[13,14,20,21]$

Childhood poisonings are generally asymptomatic due to ineffective agents or low doses, and they are usually been discharged after the pediatric emergency department observation. ${ }^{[12]}$ Symptoms of poisonings usually depend on the ingested agent. While nausea-vomiting, dizziness, and multiple nonspecific complaints are the most frequent symptoms, they can also cause life-threatening conditions such as arrhythmia, hypotension, shock, and as a result serious morbidity. ${ }^{[22,23]}$ The length of stay in the hospital, the requirement of intensive care unit and mortality depend on the agent, ingested dose, and time from ingestion to treatment. ${ }^{[7]}$ In this study, 22 (2.6\%) patients required intensive care unit admission, and it did not differ between suicidal or accidental poisonings. This result supports the idea of secondary gain in suicidal attempts.

Our study had several limitations due to its retrospective design. The time from ingestion to admission to the hospital is an important prognostic factor and we could not evaluate this subject because of the lack of data. In addition, the source of the drugs ingested was another lacked data. A comprehensive multicenter prospective study is needed to evaluate all sides of childhood poisoning and improve precautions according to the risk factors. 


\section{CONCLUSION}

Childhood poisoning is one of the important emergencies that need attention. Patients may admit in various clinical conditions such as asymptomatic or in a coma. Pediatric emergency physicians should always keep in mind the possibility of poisoning, even with the lack of medical history. It could be estimated the possible ingested agents according to the age group, and this allows physicians to avoid delay in treatment of these patients.

\section{ETHICAL DECLARATIONS}

Ethics Committee Approval: Aksaray Education and Research Hospital Scientific Research Evaluation Committee with decision no: 2021/01-54.

Informed Consent: Because the study was designed retrospectively, no written informed consent form was obtained from patients.

Referee Evaluation Process: Externally peer-reviewed.

Conflict of Interest Statement: The author(s) declared no potential conflicts of interest with respect to the research, authorship, and/or publication of this article.

Financial Disclosure: The authors declared that this study has received no financial support.

Author Contributions: All of the authors declare that they have all participated in the design, execution, and analysis of the paper, and that they have approved the final version.

\section{REFERENCES}

1. Lamireau T, Llanas B, Kennedy A, et al. Epidemiology of poisoning in children: a 7-year survey in a paediatric emergency care unit. Eur J Emerg Med 2002;9(1):9-14.

2. Gummin DD, Mowry JB, Beuhler MC, et al. 2019 Annual Report of the American Association of Poison Control Centers' National Poison Data System (NPDS): 37th Annual Report. Clin Toxicol 2020;58(12):1360-541.

3. BudnitzDS, Lovegrove MC. The last mile:taking the final steps in preventing pediatric pharmaceutical poisonings. J Pediatr 2012;160(2):190-2.

4. Lin Y-R, Wu T-K, Liu T-A, et al. Poison exposure and outcome of children admitted to a pediatric emergency department. World J Pediatr 2011;7(2):143-9.

5. Gokalp G. Evaluation of poisoning cases admitted to pediatric emergency department. Int J Pediatr Adolesc Med 2019;6(3):109-14.

6. Lam LT. Childhood and adolescence poisoning in NSW, Australia: an analysis of age, sex, geographic, and poison types. Injury Prevent 2003;9(4):338-42

7. Lin Y-R, Liu T-H, Liu T-A, et al. Pharmaceutical poisoning exposure and outcome analysis in children admitted to the pediatric emergency department. Pediatr Neonatol 2011;52(1):11-7.

8. Özdemir D, Yiş U, Kalkan Ş, et al. AKUT ÇOCUKLUK ÇAĞI ZEHIRLENMELERI. 2003.

9. Özdemir R, Bayrakci B, Teksam Ö, et al Thirty-three-year experience on childhood poisoning. Turk J Pediatr 2012;54(3):251.

10. Yang CC, Wu J-F, Ong H-C, et al. Children poisoning in Taiwan. Indian J Pediatr 1997;64(4):469-83.

11. Lin L-J, Lin T-J, Shih Y-L, et al. The patients presented in emergency department with poisoning exposure, 1995-2002. J Emerg Med Taiwan. 2003;5(4):181-9.
12. Ağın H, Çalkavur Ş, Olukman Ö, et al. Çocukluk çağında zehirlenmeler: son 2 yıldaki olguların değerlendirilmesi. T Klin Pediatri 2002;11:186-93.

13. Öner N, İnan M, Vatansever Ü, et al. Trakya bölgesinde çocuklarda görülen zehirlenmeler. Türk Pediatri Arşivi. 2004;39(1):25-30.

14. Akbay-Öntürk Y, Uçar B. Eskişehir bölgesinde çocukluk çağı zehirlenmelerinin retrospektif değerlendirilmesi. Çocuk Sağlığı ve Hastalıkları Derg 2003;46:103-13.

15. Arapoğlu M, Keskin C, Telhan L, et al. Şişli Etfal Hastanesi 1. Çocuk Kliniği'ne başvuran zehirlenme olgularının değerlendirilmesi. Şişli Etfal Tıp Bülteni. 2005;39(4):41-5.

16. Aji DY. İstanbul Üniversitesi Cerrahpaşa Tıp Fakültesi Çocuk Sağlığı ve Hastalıkları Anabilim Dalı'nda 2000-2006 yıllarında ölen olguların değerlendirilmesi. Türk Pediatri Arşivi. 2007;42(4):148-52.

17. Ayoğlu FN, Ayoğlu H, Kaptan YM, et al. A Retrospective Analysis of Cases with Acute Poisoning in Zonguldak, Turkey. Journal of the Turkish Anaesthesiology \& Intensive Care Society-JTAICS/Türk Anestezi ve Reanimasyon Derg 2009;37(4).

18. Akbaba M, Nazlican E, Demirhindi H, et al. Etiological and demographical characteristics of acute adult poisoning in Adana, Turkey. Hum Exp Toxicol 2007;26(5):401-6.

19. Seydaoglu G, Satar S, Alparslan N. Frequency and mortality risk factors of acute adult poisoning in Adana, Turkey, 1997-2002. Mount Sinai J Med 2005;72(6):393.

20. Andýran N, Sarýkayalar F. Pattern of acute poisonings in childhood in Ankara: what has changed in twenty years. Turkish J Pediatr 2004;46:14752.

21. Yorulmaz A, Akbulut $H$, Yahya I, et al. Retrospective Evaluation of Patients Admitted to the Pediatric Emergency Department with Intoxication. Cocuk Acil ve Yogun Bakım. 2017;4(3):96.

22. Özcan T, Tosun A, İnan G, et al. Hastanemize başvuran zehirlenme olgularının değerlendirilmesi. 2002.

23. Kahveci M, Çeltik C, Karasalihoğlu S,et al. Bir üniversite hastanesi acil servisine başvuran çocukluk çağı zehirlenmelerinin değerlendirilmesi. Sted. 2004;13(1):19-21. 